\title{
Fish! A Remarkable Way to Boost Morale and Improve Results
}

By Stephen C. Lundin, Harry Paul, and John Christensen

Hyperion Press, New York, 2000, 112 pages

\section{Reviewed by Gregory V. Wolcott}

San Jose State University

Student Affairs professionals are constantly looking for new ways to invigorate their work, their departments, and their programs. This is especially true for those in orientation, as the details of program planning, recruiting and hiring staff take away time for reflection on ways to improve work and relationships.

Fish! A Remarkable Way to Boost Morale and Improve Results provides a light-hearted but intelligent look at how certain business become truly "world famous." The example used that of the World Famous Pike Place Fish Market in Seattle, Washington. The book was inspired by the video produced by John Christensen about the fish market, and is a story about learning to love your work, even if it is not the "ideal" setting or the ideal job. The foreword suggested that certain life circumstances get in the way of having the "perfect job," and that whatever the reasons are for selfimprovement, the story teaches to love what we do, even if at that moment we may not be doing exactly what we love.

The book is a fast read of 112 pages, and it is easy to get lost in the story. The story's main character is Mary Jane Ramirez, who moved to Seattle with her husband Dan and two children. Mary Jane was confident she would find work, and within one month of moving, found a supervisory position in the operations area at First Guarantee Financial. Suddenly Mary Jane's husband dies and she is left with her two children without a plan for her family's future.

At this difficult time Mary Jane began to question her career path. Although Mary Jane was considered an effective supervisor and well liked at her workplace, she was not feeling a sense of belonging at First Guarantee. She was doing a wonderful job on the first floor, and production was never better. In contrast to Mary Jane's effective first floor staff, the third floor was considered the place where work orders go to die. The third floor was the large operations unit of the company, and therefore most of the company's transactions must go through it. Imagine Mary Jane's surprise when she was asked to move to the third floor as its supervisor!

Mary Jane quickly realized that the third floor deserved its reputation of being one that "sucks the life right out of you." Although Mary Jane liked many of the individuals, she noticed that hardly anything got them excited about their work. Many of the employees endure a short day's work for a low day's pay, and have done things the same way for several years. Mary Jane began to write in a journal all of her experiences and ponderings about the third floor, searching for a way to improve the situation, and her own. 
For most third floor employees, they were just doing their jobs and "hoping that retirement would come before change." Typical of a supervisor, Mary Jane was aware of the cold hard facts that her employees were not: if the company, and in particular the third floor, did not improve, many employees would be looking for new jobs. She was also feeling pressure from her supervisor, Bill, who refered to the third floor as a "toxic energy dump." Bill directed Mary Jane that she had only a few weeks to turn the department around.

Mary Jane began to wonder how in the world she would improve her workplace, and took a walk one day at lunchtime to ponder her options. She later realized how important that stroll would become. Mary Jane happened upon the world famous Pike Place Fish Market. She watched as one of the workers picked up a large fish, threw it several feet through the air, and yelled, "One salmon flying away to Minnesota," much to the delight of the gathered crowd. Mary Jane noticed how all the workers seemed to be having the time of their lives!

Mary Jane was soon approached by one of the market mongers, Lonnie, who began to share with her the secrets to being happy at work. As a few days went by, Mary Jane continued her lunch time stroll to the fish market to learn more about how to apply the principles they utilize there to her own third floor group. Lonnie began to help her outline the four secrets to success in the workplace:

"Choose your attitude. There is always a choice about the way you do your work, even if there is not a choice about the work itself." Lonnie went on to explain that this was the hardest but most important lesson to learn. Workers choose to bring a grouchy, irritable attitude to the workplace, or one that is "sunny, playful, and cheerful." Mary Jane had a hard time accepting this "choice," and explained that she had too much invested in being a victim. But because this was the first step, Mary Jane vowed to try and adapt it at her workplace.

The next morning, Mary Jane asked her supervisor Bill for some ideas that his boss learned from a leadership conference. At first Bill was hesitant, and Mary Jane was faced with her first real challenge: the courage to change. She found herself standing up to Bill, and demanding his respect and cooperation. Although it frightened Mary Jane to speak out against her superior, she felt better afterward and Bill seemed to respond. The next step was to present this first step to the employees she supervised in the weekly staff meeting.

Mary Jane outlined in her journal the steps necessary to introduce this topic of change, and the first step of "choosing your attitude." The steps were: call a meeting and speak from the heart; find a message that communicates the notion of choosing your attitude in a way that everyone will understand and personalize; provide motivation; and persist with faith. Speaking passionately and from the heart, Mary Jane outlined what she saw as the problems with their current workplace, and introduced the first secret to success. After some persuasion and clarification, most of the employees bought into the idea. Mary Jane explained that she had been working with a world class expert on choosing your attitude, and called for a Saturday meeting at the fish market for all to meet him. Of course, she was speaking about Lonnie.

The next few weeks sailed by and all employees had come down to Pike Place fish 
market to watch the guys in action. They learned from the workers there not only the first step to success, but also the final three steps. All four included are: "Choose Your Attitude; Play; Make Their Day; Be Present."

"Choose Your Attitude" related to choosing to have a positive attitude at work, and that this can be infectious.

"Play" related to having fun at work and being energized.

"Make Their Day" referred to including the customers in the good time. Engage them in ways that create energy and goodwill.

"Be Present" related to being fully present at work. Pay attention to what your colleagues and customers are telling you. Be externally, not internally, focused. Lonnie went on to explain that these four points alone will not drastically change the workplace and that it is important for employees to discover the 'Fish Philosophy' on their own.

At the following staff meeting, Mary Jane called for the staff to spend some time in teams to work on how the third floor would implement the new philosophy. After some "gentle negotiating," she set up four basic teams based on the four principles and asked each team to answer certain questions. The four teams did an impressive job of relating the Fish Philosophy to their own workplace, and the "toxic energy dump" seemed to exist no longer. After continued discussion, the teams developed practical implementation strategies.

At the end of the story, a plaque in her honor hangs on a third floor wall and read:

\section{Our Workplace}

As you enter this place of work please choose to make today a great day. Your colleagues, customers, team members, and you yourself will be thankful. Find ways to play. We can be serious about our work without being serious about ourselves. Stay focused in order to be present when your customers and team members most need you. And should you feel your energy lapsing, try this surefire remedy: Find someone who needs a helping hand, a word of support, or a good ear - and make their day.

Fish! is a wonderful book that offers real life examples of self-improvement. Often the ideas set forth are as relevant to one's personal life as they are to the workplace. This book is easily adaptable to any workplace, but especially relevant to student affairs professionals and groups of student leaders who have a common purpose and goal. 